\title{
Effects of active immunization against growth differentiation factor 9 and/or bone morphogenetic protein 15 on ovarian function in cattle
}

\author{
Jennifer L Juengel, Norma L Hudson, Martin Berg ${ }^{1}$, Keith Hamel, Peter Smith,
} Stephen B Lawrence, Lynda Whiting and Kenneth P McNatty

\begin{abstract}
Wallaceville Animal Research Centre, AgResearch, Upper Hutt 5140, New Zealand and ${ }^{1}$ Reproductive Technologies, Ruakura Research Centre, AgResearch, Hamilton 3214, New Zealand
\end{abstract}

Correspondence should be addressed to J L Juengel who is now at AgResearch Ltd, Invermay Agricultural Centre, Puddle Alley, Private Bag 50034, Mosgiel 9053, New Zealand; Email: jenny.juengel@agresearch.co.nz

N L Hudson and K P McNatty are now at School of Biological Sciences, Victoria University of Wellington, PO Box 600, Wellington, New Zealand

\begin{abstract}
Growth differentiation factor 9 (GDF9) and bone morphogenetic protein 15 (BMP15) are essential for ovarian follicular growth in sheep, whereas only GDF9 is essential in mice suggesting that the roles of these oocyte-derived growth factors differ among species. At present, however, there is only limited information on the action of BMP15 and GDF9 in other species. Thus, the aim of this experiment was to determine the effect of neutralizing GDF9 and/or BMP15 in vivo on ovarian follicular development and ovulation rate in cattle through active immunization using the mature regions of the proteins or peptides from the N-terminal area of mature regions. Immunization with the BMP15 peptide, with or without GDF9 peptide, significantly altered (increased or decreased) ovulation rate. In some animals, there were no functional corpora lutea (CL), whereas in others up to four $\mathrm{CL}$ were observed. From morphometric examination of the ovaries, immunization with GDF9 and/or BMP15 reduced the level of ovarian follicular development as assessed by a reduced proportion of the ovarian section occupied by antral follicles. In addition, immunization against GDF9 and/or BMP15 peptides reduced follicular size to $<25 \%$ of that in the controls. In conclusion, immunization against GDF9 and BMP15, alone or together, altered follicular development and ovulation rate in cattle. Thus, as has been observed in sheep, both GDF9 and BMP15 appear to be key regulators of normal follicular development and ovulation rate in cattle.

Reproduction (2009) 138 107-114
\end{abstract}

\section{Introduction}

The use of sheep with naturally occurring mutations in the genes for the related oocyte-derived growth factors bone morphogenetic protein 15 (BMP15) and growth differentiation factor 9 (GDF9) have demonstrated their essential role in regulating ovarian follicular growth and ovulation rate (Galloway et al. 2000, Hanrahan et al. 2004, McNatty et al. 2005b). In mice, the use of 'knock-out' models has shown that GDF9 is essential for normal follicular development with BMP15 regulating the fertilization potential of oocytes (Dong et al. 1996, Yan et al. 2001, Chang et al. 2002). However, the role of either of these growth factors in regulating ovulation rate in mice is equivocal. Recently, naturally occurring mutations in either GDF9 or BMP15 in humans have been linked to infertility, including primary amenorrhea (Di Pasquale et al. 2004, 2006, Dixit et al. 2005, 2006, Laissue et al. 2006, Kovanci et al. 2007), and for GDF9, to increased dizygotic twinning (Palmer et al. 2006). Thus, one or both of these growth factors likely play a critical role in ovarian follicular development in mammals, although the absolute requirement and specific roles of the growth factors vary between species, potentially related to the ovulation rate quota of a particular species (Moore et al. 2004).

Sheep that are homozygous for inactivating mutations of BMP15 or GDF9 are infertile with primary ovarian failure (McNatty et al. 2005b). However, those heterozygous for inactivating mutations of either BMP15 or GDF9 are fertile, with increased ovulation rates (McNatty et al. 2003). This rather unusual phenotype is related to the function of GDF9 and BMP15 in co-operatively regulating granulosa cell proliferation and differentiation (McNatty et al. 2005a). Proliferation of granulosa cells of ewes lacking any active BMP15 or GDF9 is insufficient to support the development of the 
follicle to ovulation (Juengel et al. 2004a). By contrast, with one gene inactivated, it is postulated that the reduced bioactivity of the growth factors leads to the development of follicles that mature earlier in follicular growth than normal with fewer granulosa cells (Juengel et al. 2004a). As FSH concentrations during the follicular phase are regulated by the products from these granulosa cells, namely estradiol and inhibin, more follicles develop LH receptors on the granulosa cells and thus advance to a stage that they can survive in the low FSH environment that is induced through the actions of the granulosa cells of the maturing follicles. In this manner, a greater number of follicles ovulate at each reproductive cycle (Juengel et al. 2004a).

This effect on ovulation rate can be mimicked in sheep by artificially manipulating their levels of BMP15 or GDF9 through active immunization (Juengel et al. 2002, 2004b, McNatty et al. 2007). Immunization regimens designed to provide high concentrations of antibodies that will neutralize BMP15 or GDF9 result in a cessation of reproductive cycles with the development of follicles altered from a very early stage of development (Juengel et al. 2002). By contrast, by selecting an immunization regime to produce a lesser antibody response, enhanced ovulation rates can be achieved, with individual animals ovulating as many as ten oocytes (Juengel et al. 2002). Thus, active immunization of animals with GDF9 and/or BMP15 is a very useful tool for assessing the potential roles of these growth factors on reproductive function in vivo.

While GDF9 and BMP15 have both been shown to regulate granulosa and/or theca function in vitro (McNatty et al. 2005a, Spicer et al. 2006, 2008), the role of GDF9 and BMP15 in regulating ovulation rate or ovarian follicular development in vivo in cattle is unknown. As with sheep and humans, cattle are a species with a low ovulation rate phenotype, thus if the ovulation rate quota hypothesis was correct, both GDF9 and BMP15 would be expected to be essential for the regulation of follicular growth and ovulation rate. Therefore, the objectives of this experiment in cattle were to explore the role of GDF9 and BMP15 in the regulation of ovarian follicular growth and ovulation rate using active immunization to modulate the bioactivity of the growth factors.

\section{Results}

\section{Immune response}

Heifers immunized with GDF9 alone (Escherichia coli protein or peptide) had measurable antibodies to GDF9 but not BMP15 (Table 1), whereas those immunized with BMP15 alone (E. coli protein or peptide) had measurable antibodies to BMP15 but not GDF9 (Table 1). Heifers immunized with GDF9 and BMP15 had measurable antibodies to both proteins (Table 1).

\section{Ovulation rate}

The ovulation rate of heifers immunized with GDF9 alone was not significantly different from the ovulation rate of the control heifers (Table 2). Ovulations rates of animals immunized with BMP15 peptide, but not the mature protein, were different from keyhole-limpet hemocyanin (KLH)-immunized control heifers (Table 2). Some heifers immunized with BMP15 peptide alone appeared not to have ovulated (Fig. 1), whereas others immunized with BMP15 alone or with GDF9 peptide had increased ovulation rates with four corpora lutea $(\mathrm{CL})$ observed in some animals immunized with both GDF9 and BMP15 peptides (Fig. 1).

\section{Follicular development}

As expected, follicular and oocyte diameters increased as the follicles progressed from type 1 to type 2 follicles. Overall, immunization with BMP15 with or without GDF9 tended to increase follicular/oocyte diameter in type $1,1 \mathrm{a}$, and 2 follicles, particularly when the peptides to GDF9 and/or BMP15 were used as antigens (Table 3; Fig. 2). Significant increases in follicular and oocyte diameters in type 1 follicles were also observed in the

Table 1 Average optical densities (ELISA data) of bovine sera collected pre- or post-immunization (just before ovarian collection) when measured by ELISA to determine the immunization responses to keyhole-limpet hemocyanin (KLH), growth differentiation factor 9 (GDF9), and/or bone morphogenetic protein 15 (BMP15).

\begin{tabular}{|c|c|c|c|c|}
\hline \multirow[b]{3}{*}{ Immunization treatment } & \multicolumn{4}{|c|}{ Coating antigen } \\
\hline & \multicolumn{2}{|c|}{ GDF9 } & \multicolumn{2}{|c|}{ BMP15 } \\
\hline & Pre-immunization & Post-immunization & Pre-immunization & Post-immunization \\
\hline KLH & $0.40 \pm 0.09$ & $0.32 \pm 0.05$ & $0.05 \pm 0.01$ & $0.23 \pm 0.18$ \\
\hline GDF9 mature region-KLH & $0.50 \pm 0.22$ & $1.58 \pm 0.24^{*}$ & $0.35 \pm 0.21$ & $0.23 \pm 0.05$ \\
\hline BMP15 mature region-KLH & $0.42 \pm 0.11$ & $0.32 \pm 0.40$ & $0.14 \pm 0.03$ & $2.10 \pm 0.23^{\dagger}$ \\
\hline GDF9 peptide-KLH & $0.46 \pm 0.17$ & $1.90 \pm 0.26^{\dagger}$ & $0.25 \pm 0.13$ & $0.42 \pm 0.20$ \\
\hline BMP15 peptide-KLH & $0.37 \pm 0.05$ & $0.35 \pm 0.04$ & $0.12 \pm 0.01$ & $1.61 \pm 0.27^{+}$ \\
\hline GDF9 and BMP15 peptides-KLH & $0.39 \pm 0.07$ & $1.15 \pm 0.16^{\dagger}$ & $0.13 \pm 0.01$ & $1.12 \pm 0.28^{\dagger}$ \\
\hline
\end{tabular}

${ }^{*} P<0.05,{ }^{\dagger} P<0.01$ comparing pre-immunization to post-immunization within a treatment. 
Table 2 Ovulation rate distributions in heifers at ovarian collection after immunization with keyhole-limpet hemocyanin (KLH), growth differentiation factor 9 (GDF9), and/or bone morphogenetic protein 15 (BMP15).

\begin{tabular}{|c|c|c|c|c|c|}
\hline \multirow[b]{2}{*}{ Treatment } & \multicolumn{5}{|c|}{ Ovulation rate } \\
\hline & 0 & 1 & 2 & $>3$ & $\chi^{2}$ \\
\hline KLH & 0 & 9 & 1 & 0 & \\
\hline GDF9 mature region-KLH & 0 & 8 & 2 & 0 & NS \\
\hline BMP15mature region-KLH & 0 & 6 & 4 & 0 & NS \\
\hline GDF9 peptide-KLH & 0 & 7 & 3 & 0 & NS \\
\hline BMP15 peptide-KLH & 3 & 3 & 4 & 0 & $<0.01$ \\
\hline GDF9 and BMP15 peptides-KLH & 0 & 4 & 2 & 4 & $<0.05$ \\
\hline
\end{tabular}

For $\chi^{2}$ analysis, animals were assigned as normal (ovulation rate of 1 ) or affected (ovulation rate of 0 or $>2$ ) with each treatment group compared to KLH control group. NS, not significantly different.

animals immunized with GDF9 mature region, but the mean diameter of type 2 follicles was decreased in these same animals relative to the $\mathrm{KLH}$ controls. At the time of ovarian collection, it was noted that animals immunized with BMP15 and GDF9, particularly those immunized with the peptide antigens, had a reduced presence of follicles visible on the surface of the ovary (Fig. 1). Quantification of the effects of treatment on follicular growth revealed that immunization with GDF9 and/or BMP15 decreased the area of the ovarian section that was occupied by antral space (Table 4; Fig. 3). In addition, overall, immunization with GDF9 and/or BMP15 antigen decreased the numbers of follicles, and immunization with GDF9 and/or BMP15 peptide antigens decreased the average diameter of the follicle (Table 4; Fig. 3).

\section{Discussion}

Neutralization of either GDF9 or BMP15, alone or together, resulted in alterations of ovarian follicular development in vivo indicating that both GDF9 and BMP15 are likely regulators of ovarian follicular development in cattle. Thus, the roles of GDF9 and BMP15 in cattle appear more similar to those observed in other species with a low ovulation rate phenotype, such as sheep and humans, than species with a high ovulation rate phenotype, such as mice.

From previous studies in sheep either immunized against BMP15 or GDF9 or lacking an active BMP15 protein, it is known that the development of follicles is affected very early in follicular development (Braw-Tal et al. 1993, Juengel et al. 2002). Likewise, follicular growth is blocked at a very early stage in mice lacking functional GDF9 (Dong et al. 1996), and increasing the amounts of GDF9 or BMP15 available in vivo increased the growth of small follicles (Vitt et al. 2000, Shimizu et al. 2004, McMahon et al. 2008). In the present study, differences in oocyte and/or follicular diameters of type 1 , $1 \mathrm{a}$, and 2 follicles indicate that BMP15 and GDF9 may also regulate follicular growth during the earliest stage of follicular development in cattle. In cattle as in sheep, GDF9 is known to be expressed in type 1, 1a, and 2 follicles (Bodensteiner et al. 1999), and given that the receptor subtypes are likely to be present in cattle as in sheep (Fatehi et al. 2005, Juengel \& McNatty 2005), it is perhaps reasonable to assume that the neutralization of GDF9 by active immunization is having a direct effect on follicles at these stages. Oocyte diameter is enlarged in mice lacking an active Gdf9 gene (Carabatsos et al. 1998) and in sheep immunized against GDF9 (Juengel et al. 2002). In most species, BMP15 is not expressed until the primary (type 2) stage, although the likely receptors for BMP15 are expressed earlier (Juengel et al. 2004a, Juengel \& McNatty 2005). Thus, it is possible that the effects on follicular diameter observed in heifers immunized with a BMP15 antigen are indirect or a result of BMP15 produced by a more advanced follicle. Another more likely explanation might be that the
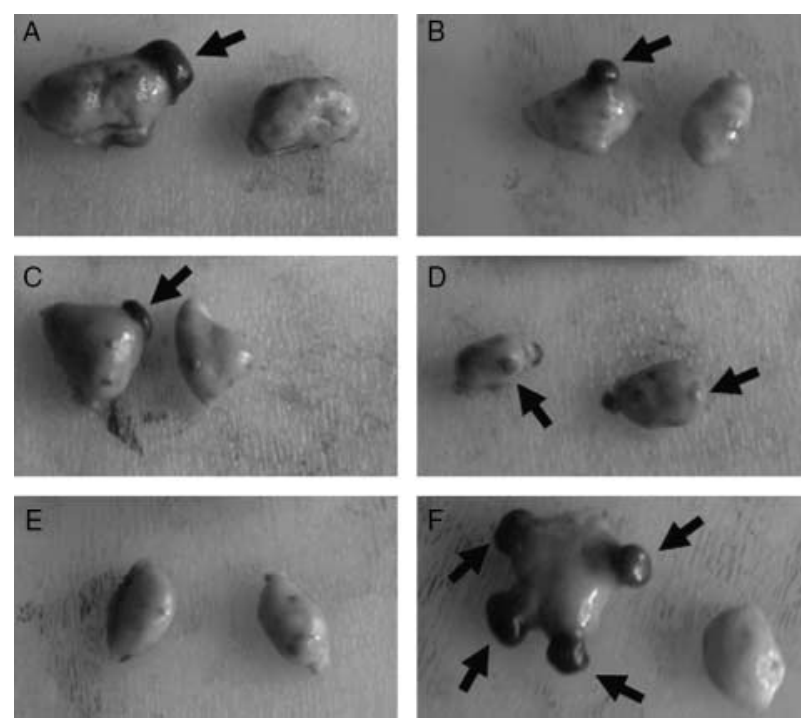

Figure 1 Ovaries collected from heifers immunized with (A) keyholelimpet hemocyanin (KLH), (B) growth differentiation factor 9 (GDF9) mature protein conjugated to $\mathrm{KLH},(\mathrm{C})$ bone morphogenetic protein 15 (BMP15) mature protein conjugated to KLH, (D) GDF9 peptide conjugated to $\mathrm{KLH}$, (E) BMP15 peptide conjugated to KLH, or (F) GDF9 and BMP15 peptides conjugated to KLH. Arrows denote corpora lutea. Note that blood vessels of the hilus of the ovary also present as darker shading (e.g. see top of left ovary in panel D). 
Table 3 Average follicular and oocyte diameters of types 1, 1a, and 2 follicles in heifers immunized with keyhole-limpet hemocyanin (KLH), growth differentiation factor 9 (GDF9), and/or bone morphogenetic protein 15 (BMP15).

\begin{tabular}{|c|c|c|c|c|c|c|}
\hline \multirow[b]{3}{*}{ Treatment group } & \multicolumn{6}{|c|}{ Type of follicle } \\
\hline & \multicolumn{2}{|c|}{ Type 1} & \multicolumn{2}{|c|}{ Type 1a } & \multicolumn{2}{|c|}{ Type 2} \\
\hline & $\begin{array}{c}\text { Follicular } \\
\text { diameter }(\mu \mathrm{m})\end{array}$ & $\begin{array}{c}\text { Oocyte } \\
\text { diameter }(\mu \mathrm{m})\end{array}$ & $\begin{array}{c}\text { Follicular } \\
\text { diameter }(\mu \mathrm{m})\end{array}$ & $\begin{array}{c}\text { Oocyte } \\
\text { diameter }(\mu \mathrm{m})\end{array}$ & $\begin{array}{c}\text { Follicular } \\
\text { diameter }(\mu \mathrm{m})\end{array}$ & $\begin{array}{c}\text { Oocyte } \\
\text { diameter }(\mu \mathrm{m}) \\
\end{array}$ \\
\hline KLH & $32.8 \pm 0.5$ & $25.6 \pm 0.4$ & $39.4 \pm 0.8$ & $28.3 \pm 0.5$ & $56.0 \pm 1.2$ & $32.6 \pm 0.6$ \\
\hline GDF9 mature region-KLH & $34.7 \pm 0.7^{*}$ & $27.7 \pm 0.6^{+}$ & $41.6 \pm 0.9$ & $29.6 \pm 0.5^{\neq}$ & $49.5 \pm 1.3^{*}$ & $31.1 \pm 0.8$ \\
\hline BMP15 mature region-KLH & $34.4 \pm 0.5^{\neq}$ & $26.8 \pm 0.5$ & $40.9 \pm 0.6$ & $29.1 \pm 0.5$ & $62.1 \pm 2.0$ & $35.3 \pm 1.8$ \\
\hline GDF9 peptide-KLH & $33.8 \pm 0.5$ & $25.6 \pm 0.5$ & $40.2 \pm 0.7$ & $27.9 \pm 0.4$ & $58.9 \pm 1.6$ & $33.1 \pm 1.0$ \\
\hline BMP15 peptide-KLH & $34.9 \pm 0.6^{*}$ & $26.7 \pm 0.5$ & $42.9 \pm 0.9^{*}$ & $28.9 \pm 0.5$ & $59.3 \pm 1.7^{\ddagger}$ & $32.6 \pm 0.8$ \\
\hline $\begin{array}{l}\text { GDF9 and BMP15 } \\
\text { peptides-KLH }\end{array}$ & $34.2 \pm 05$ & $26.5 \pm 05$ & $42.6 \pm 07^{*}$ & $29.9 \pm 04^{*}$ & $60.8 \pm 18^{\ddagger}$ & $33.9 \pm 09$ \\
\hline
\end{tabular}

Within each follicular type, ${ }^{*}{ }^{+}$indicate a significant difference $\left({ }^{*} P<0.05 ;{ }^{\dagger} P<0.01\right)$ when compared with $\mathrm{KLH}$ group, ${ }^{*}$ indicates a tendency $(P<0.10)$ for a difference to KLH control group.

classification system for the follicles, which relies on granulosa cell phenotype, could be altered such that follicles that developmentally are actually type 2 follicles would still be classified as type 1 or 1 a follicles. An observation in support of this explanation is the presence of abnormal follicles in ewes, which are homozygous for inactivating mutations in BMP15 (Braw-Tal et al. 1993). In these animals, oocyte enlargement was observed independent of changes in granulosa cell number or morphology resulting in type $1 / 1$ a follicles with abnormally enlarged oocytes. Similar structures have also been observed in ewes immunized with either GDF9 or BMP15 (Juengel et al. 2002, McNatty et al. 2007).

Effects of BMP15 and/or GDF9 on granulosa and/or theca cell function have been observed in vitro (McNatty et al. 2005a, Spicer et al. 2006, 2008). Granulosa cell proliferation is stimulated by GDF9 and/or BMP15, whereas steroidogenesis is inhibited (McNatty et al. 2005a, Spicer et al. 2006). GDF9 has also been postulated to have a role in the regulation of the theca, although it has yet to be proven that GDF9 crosses the basement membrane of the follicle. Treatment of theca cells with GDF9 also induced proliferation and inhibited steroidogenesis indicating a potential role for GDF9 in the regulation of theca function (Spicer et al. 2008). A role for GDF9 in theca function has also been observed in rodent models in vivo (Vitt et al. 2000, Wu et al. 2004). Histologically, the most striking feature observed following immunization with either GDF9 or BMP15 was the reduction in the numbers of antral follicles observed, particularly in the peptide-immunized animals. This characteristic was noted macroscopically at the time of ovarian collection and was confirmed by microscopic and morphometric evaluation. The reduction in antral space was associated with both a decreased number and size of antral follicles observed. A decrease in the number of antral follicles, particularly larger antral follicles, was also observed in sheep immunized against either BMP15 or GDF9 (Juengel et al. 2002). Increasing the amounts of GDF9 or BMP15 available in vivo also increased the growth of small follicles (Vitt et al. 2000, Shimizu et al. 2004, McMahon et al. 2008), indicating a central role for these growth factors in stimulating follicular growth.
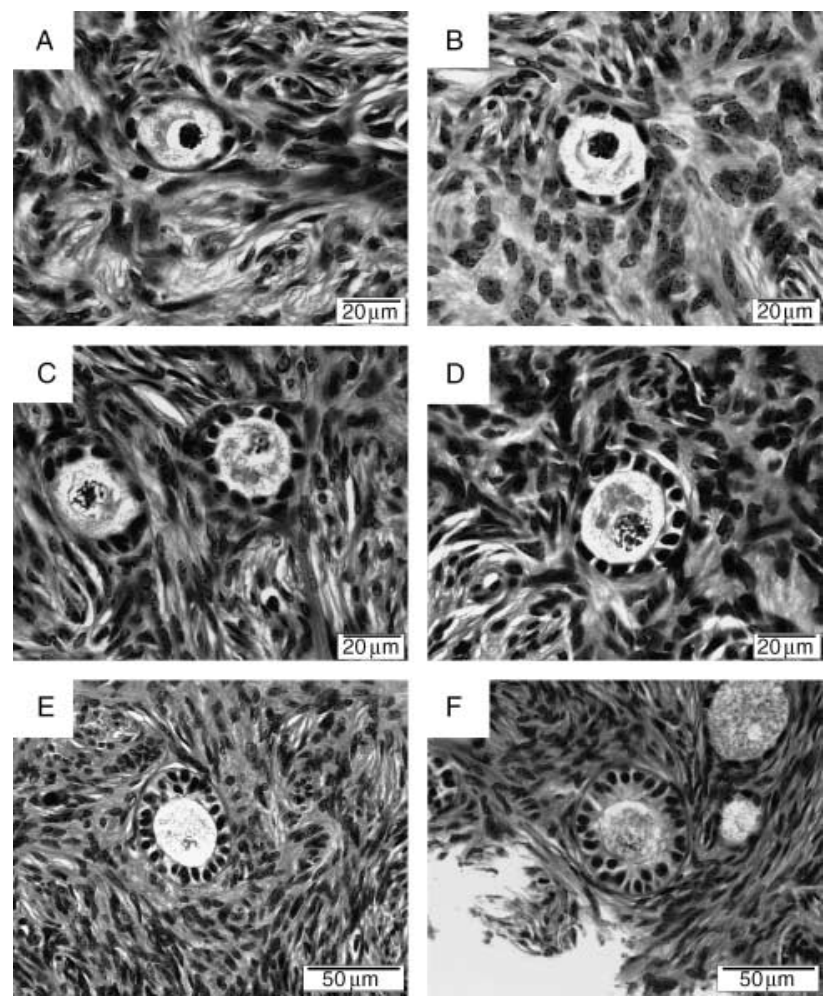

Figure 2 Photomicrographs of ovarian sections collected from heifers immunized against (A, C, and E) keyhole-limpet hemocyanin $(\mathrm{KLH})$, (B) growth differentiation factor 9 (GDF9) mature region protein conjugated to $\mathrm{KLH}$, (D) GDF9 and bone morphogenetic protein 15 (BMP15) peptides conjugated to KLH, or (F) BMP15 peptide conjugated to KLH. Panels A and B show type 1 follicles of 31 and $35.5 \mu$ m diameter respectively, $\mathrm{C}$ and $\mathrm{D}$ display type 1 a follicles of 37 and $42.5 \mu \mathrm{m}$ diameter respectively, and $E$ and $F$ contain type 2 follicles of 53.5 and $63 \mu \mathrm{m}$ diameter respectively. The follicles presented were selected to represent the approximate mean diameter of their respective groups. Note that follicles from heifers immunized with GDF9 and/or BMP15 overall were slightly larger than those from heifers immunized with KLH (control). 
Table 4 Average percentage of tissue section area occupied by antral space, total number of antral follicles corrected for area, and average follicular area in heifers immunized with keyhole-limpet hemocyanin (KLH), growth differentiation factor 9 (GDF9), and/or bone morphogenetic protein 15 (BMP15).

\begin{tabular}{lccccc}
\hline Treatment group & $\begin{array}{c}\text { Number of } \\
\text { ovaries } \\
\text { examined }\end{array}$ & $\begin{array}{c}\text { Total number of } \\
\text { sections } \\
\text { examined }\end{array}$ & $\begin{array}{c}\text { Percentage of tissue } \\
\text { section area occupied } \\
\text { by antral space }\end{array}$ & $\begin{array}{c}\text { Total number of } \\
\text { follicles corrected } \\
\text { for area }\left(100 \mathrm{~mm}^{2}\right)\end{array}$ & $\begin{array}{c}\text { Average } \\
\text { follicular } \\
\left.\text { area }^{2} \mathrm{~mm}^{2}\right)\end{array}$ \\
\hline KLH & 10 & 72 & $27.4 \pm 2.0^{+}$ & $7.3 \pm 0.6$ & $4.0 \pm 0.5$ \\
GDF9 mature region-KLH & 10 & 73 & $20.4 \pm 1.6^{+}$ & $6.3 \pm 0.6$ & $3.5 \pm 0.4$ \\
BMP15 mature region-KLH & 10 & 66 & $12.6 \pm 3.5^{+}$ & $4.7 \pm 0.8^{*}$ & $2.6 \pm 0.5$ \\
GDF9 peptide-KLH & 8 & 47 & $1.0 \pm 0.3^{+}$ & $2.2 \pm 0.4^{+}$ & $0.4 \pm 0.1^{+}$ \\
BMP15 peptide-KLH & 8 & 46 & $1.1 \pm 0.4^{+}$ & $2.3 \pm 0.6^{+}$ & $0.4 \pm 0.1^{+}$ \\
GDF9 and BMP15 & 9 & 66 & $1.6 \pm 1.0^{+}$ & $1.6 \pm 0.3^{+}$ & $0.8 \pm 0.4^{+}$ \\
peptides-KLH & & & & & \\
\hline
\end{tabular}

$* P<0.05,{ }^{\dagger} P<0.01$ compared with control within column.

In both sheep (Juengel et al. 2002, McNatty et al. 2007) and cattle (this study), many animals continued to ovulate normal or greater than normal numbers of follicles even with an overall reduction in total numbers of antral follicles, suggesting that the follicles that continue to develop are capable of ovulation. It appears that cessation of reproductive cycles requires an almost complete inhibition of antral follicle development and that this was achieved only in a few animals in the BMP15
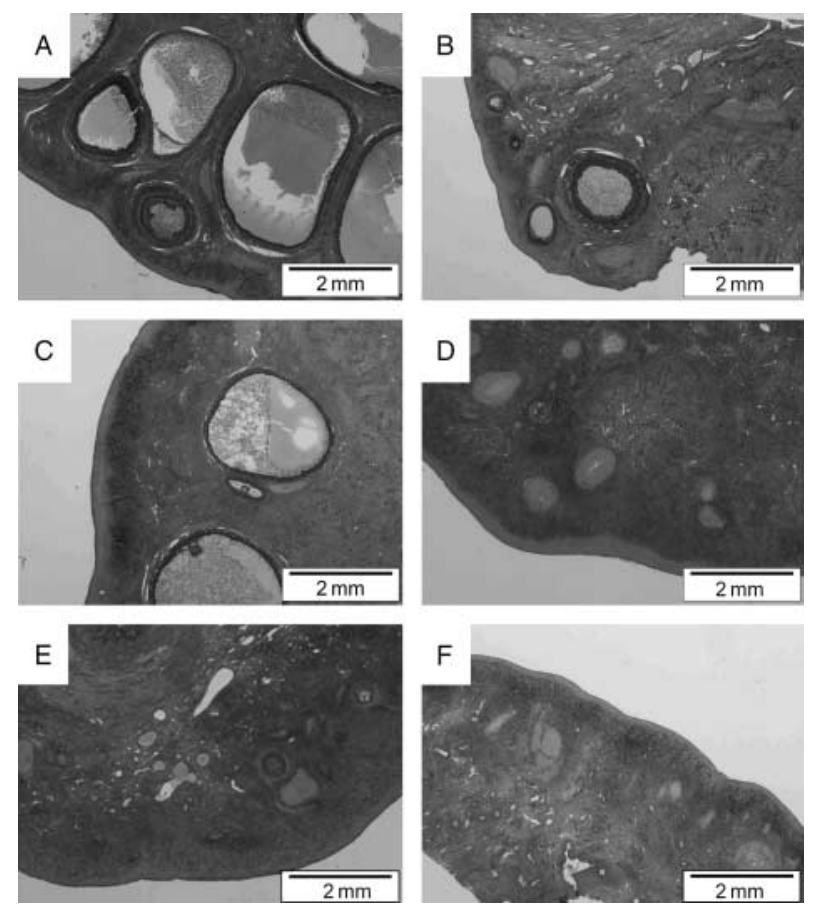

Figure 3 Photomicrographs of ovaries collected from heifers immunized with (A) keyhole-limpet hemocyanin (KLH), (B) growth differentiation factor 9 (GDF9) mature protein conjugated to KLH, (C) bone morphogenetic protein 15 (BMP15) mature protein conjugated to $\mathrm{KLH}$, (D) GDF9 peptide conjugated to KLH,

(E) BMP15 peptide conjugated to KLH, or (F) GDF9 and BMP15 peptides conjugated to KLH. Note the overall decrease in antral follicle numbers and diameters in heifers immunized with either GDF9 and/or BMP15. peptide-immunized group. It is also possible that it takes longer to shut down the development of antral follicles in cattle than in sheep. Studies in sheep immunized against BMP15 or GDF9 show that during the interval to anovulation, animals may ovulate multiple follicles (Juengel et al. 2002, McNatty et al. 2007).

In sheep, different antigens and adjuvants have been used to either enhance ovulation rate or to inhibit ovulation through suppression of ovarian follicular development (Juengel et al. 2002, 2004b, McNatty et al. 2007). A partial neutralization of GDF9 or BMP15, induced through active immunization with a waterbased adjuvant, increased ovulation rate (Juengel et al. 2004b); whereas a more complete neutralization of GDF9 or BMP15, induced through the use of an oil-based adjuvant, caused a cessation of follicular development (Juengel et al. 2002, McNatty et al. 2007). In the present study in cattle, using an oil-based adjuvant and peptides known to be very efficacious as antigens in sheep, the ability of immunization against BMP15 and/or GDF9 to regulate ovulation rate resulted in a variable outcome, with a cessation of reproductive cycles observed in some animals and an increased ovulation rate observed in others. A similar variable outcome was observed in ewes immunized with the $E$. coli-expressed mature region of BMP15 and an oil-based adjuvant, although very high ovulation rates were often observed in those sheep that continued to ovulate (Juengel et al. 2002). The variable response in the sheep studies was thought to be, in part, related to the generation of antibodies to different regions of the peptide, with some being more efficacious than others in neutralizing BMP15 and GDF9 notwithstanding the generation of high antibody titers. Further studies assessing the effectiveness of different regions of the mature regions as antigens demonstrated that some regions of the peptides were much more effective than others in inhibiting follicular development, and that this was also related to the length of time the animal had been immunized (McNatty et al. 2007). Thus, the variable responses observed in cattle immunized with the BMP15 
peptide may be related to variations in an animal's response to the immunization protocol, the timing of ovarian collection, or to differences in the roles of BMP15 and GDF9 in regulating follicular growth. It is worth noting that the BMP15 peptide used in this study, which is $100 \%$ conserved between sheep and cattle, was the most effective antigen used to inhibit follicular growth in sheep (McNatty et al. 2007) and was capable of neutralizing the actions of BMP15 in vitro (McNatty et al. 2007). One observation that may explain the apparent decrease in efficacy of immunizations against BMP15 or GDF9 to prevent ovulation is the apparent decrease in immune response of cattle compared with sheep. While it is difficult to directly compare antibody responses across species, previous measurements of antibodies in sheep immunized with very similar or identical antigens, which required a $\geq 10000$-fold dilution of sera for testing (McNatty et al. 2007), compared the 500-fold dilution of bovine sera in the present study. While the use of an ovine antigen in the ELISA could account for some of the difference in the assay, this would affect only the reading of the GDF9 peptide-immunized animals where the peptide contained one amino acid different from the ovine antigen coated on the plate. Given the similar reading for all groups, the differences in antibody titers are most likely related to differences in the amount of antibody formed rather than a failure to recognize the ovine antigen. An alternative explanation could be in species differences in the function of the growth factors. Both GDF9 and BMP15 are known to affect the final stages of follicular development in sheep, as passive immunization against these factors, 4 days before induction of the follicular phase, influenced the maturation of the preovulatory follicle and either inhibited ovulation and/or normal development of the corpus luteum (Juengel et al. 2002). Currently, it is unknown whether GDF9 and BMP15 play a similar role in the final maturation of the preovulatory follicle in cattle, but it could be postulated that if GDF9 and BMP15 were not as critical to the final stages of follicular development in cattle then neutralization of GDF9 and or BMP15 might have to completely block an earlier stage of follicular development. In support of differing roles of GDF9 and BMP15 in cattle are the observations that the functions of the growth factors in the in vitro bioassays, while very similar, were not identical (McNatty et al. 2005a). Future studies to enhance immune response as well as better understanding of the roles that GDF9 and BMP15 play in regulating follicular development in cattle are needed to fully address these questions.

In summary, immunization against BMP15 and/or GDF9 resulted in alteration of ovarian follicular development in cattle. It is concluded that, as in sheep, both growth factors have important roles in regulating ovarian follicular development and ovulation rate in cattle.

\section{Materials and Methods}

All experiments were performed in accordance with the 1999 Animal Welfare Act Regulations of New Zealand. Except where indicated, laboratory chemicals were obtained from BDH Chemicals New Zealand Ltd (Palmerston North, New Zealand), or Sigma-Aldrich New Zealand Ltd.

\section{Immunizations and tissue collection}

Post-pubertal Holstein cross-bred heifers (weight $394 \pm 3 \mathrm{~kg}$ ) were allotted to treatment group by weight such that the average weight of each group was similar. All animals had normal ovarian morphology at the start of the experiment as assessed by ultrasound. Heifers ( $n=10$ per group) were immunized three times at 4-weekly intervals using a Freund's complete adjuvant for the primary immunization and a Span-Tween-Marcol adjuvant for the booster immunizations. Treatment groups consisted of $\mathrm{KLH}$ control; $0.4 \mathrm{mg}$ antigen primary and $0.2 \mathrm{mg}$ antigen boosters, E. coli expressed ovine GDF9 mature region conjugated to $\mathrm{KLH}(0.8 \mathrm{mg}$ antigen primary and $0.4 \mathrm{mg}$ antigen boosters), E. coli expressed ovine BMP15 mature region conjugated to $\mathrm{KLH}(0.8 \mathrm{mg}$ antigen primary and $0.4 \mathrm{mg}$ antigen boosters), GDF9 peptide (amino acids 1-14 of the mature region of the bovine protein; $0.4 \mathrm{mg}$ antigen primary and $0.2 \mathrm{mg}$ antigen boosters) conjugated to KLH, BMP15 peptide (amino acids $1-14$ of the mature region of the bovine protein; $0.4 \mathrm{mg}$ antigen primary and $0.2 \mathrm{mg}$ antigen boosters) conjugated to $\mathrm{KLH}$, and both GDF9 and BMP15 peptide conjugated to KLH $(0.4 \mathrm{mg}$ of each antigen primary and $0.2 \mathrm{mg}$ of each antigen boosters). Blood samples were collected at the time of the first immunization and every 2 weeks until the end of the experiment for determination of antibody titers and progesterone concentrations. Estrous cycles of all heifers were sychronized prior to collection of the ovaries using two injections of Estrumate (500 $\mu$ g, Schering-Plough Animal Health Ltd, Upper Hutt, New Zealand) given 12 days apart. The second injection of Estrumate was given 30 days prior to ovarian collection. Ovaries were collected from heifers at slaughter $\sim 2$ weeks after the final immunization. At collection, the number and appearance of $\mathrm{CL}$ were noted and ovaries were fixed in Bouin's fluid for histological examination. To aid penetration of fixative, two cuts, at right angles to each other, were made approximately seven-eighths of the way into the ovary.

\section{Determination of immune response}

Antibodies directed against GDF9 or BMP15 were measured by ELISA as previously described (Juengel et al. 2002) with minor modifications. The modifications were that the antigen coated onto the microtiter plates was 200 ng of ovine GDF9 mature protein or $100 \mathrm{ng}$ of ovine BMP15 mature protein. While the peptide used for BMP15 is identical between sheep and cattle, that used for GDF9 differs by one amino acid. The mature regions of ovine and bovine GDF9 and BMP15 both share $97 \%$ amino acid identity. Sera from heifers were diluted to 1:500. Antibodies were detected using a 1:20 000 dilution of a rabbit anti-bovine IgG. 


\section{Determination of ovulation rate}

Ovulation rate was assessed by counting the number of $\mathrm{CL}$ visible on the surface of the ovary. CL were considered to have regressed (and thus not counted in ovulation rate score) if they appeared non-functional by morphological criteria (small, lacking vascularization, and pale colour) and endocrinological criteria (low levels of progesterone in blood samples collected 2 weeks before and at the time of ovarian collection). Progesterone was measured in a single RIA (McNatty et al. 1981). The sensitivity of the assay was $0.1 \mathrm{ng} / \mathrm{ml}$ and the coefficient of variation was $10.2 \%$.

\section{Assessment of follicular development}

Follicular development was assessed on $5 \mu \mathrm{m}$ histological sections stained with hematoxylin and eosin. Ovaries from five animals (two in the GDF9 peptide group, two in the BMP15 peptide group, and one in the GDF9 and BMP15 peptide groups) were lost during ovarian processing and thus were not included in further analysis. Given the large size of the ovaries, following fixation but prior to embedding in paraffin, ovaries were cut into pieces (approximately six or seven pieces per ovary). A single $5 \mu \mathrm{m}$ histological section was obtained from each piece of ovary (i.e. six to seven slides were examined from each animal with the sections being from different parts of the ovary). For type 1, 1a, and 2 follicles, the follicular and oocyte diameters were measured in each group. A type 1 follicle contained an oocyte surrounded by a single layer of flattened granulosa cells, whereas a type 1a follicle contained both flattened and cuboidal shaped granulosa cells. A type 2 follicle contained at least one but $<2$ complete layers of cuboidal granulosa cells around the oocyte. In addition, the percentage of the total area of the section occupied by antral space, the number of antral follicles per unit area of the histological section examined, and the average size (area) of antral follicles were measured on each slide that was examined. Variation in measurements for antral space, the number of antral follicles per unit of area, and average size of the antral follicle due to differing follicular structures represented in each slide were examined by comparing values obtained after analysis of four slides to the final values obtained for ten animals. The average variation between values obtained from four slides and the final values was $<10 \%$, indicating sufficient slides were examined to obtain a representative measurement for each animal.

\section{Statistical analyses}

Differences in the optical density readings from ELISAs to measure antibodies in sera samples collected prior to immunization and at the time of ovarian collection were compared using a paired $t$-test. Differences in ovulation rate of animals immunized with GDF9 and/or BMP15 to KLH controlimmunized animals were determined by $\chi^{2}$ analyses following classification of the ovulation rates observed as normal (ovulation rate of 1 ) or affected (ovulation rate of 0 or $\geq 2$ ). Diameters of type 1, 1a, and 2 follicles and oocytes were transformed (natural log) prior to analyses. The percentages of the ovarian section occupied by antral space were arc sine transformed prior to analyses and the numbers of follicles per unit area and average follicular area were transformed (natural log) also. Differences among groups were assessed by ANOVA followed by Fisher's least significant difference method using the Minitab 15.1 programme. The means and standard errors of the mean of the untransformed data are presented.

\section{Declaration of interest}

AgResearch holds patents related to the use of modulation of BMP15 and GDF9 in the regulation of ovarian function and ovulation rate. Both Jennifer Juengel and Ken McNatty are listed as inventors on those patents. However, both Jenny Juengel and Ken McNatty have assigned their ownership in these patents to AgResearch.

\section{Funding}

This research was supported by the Foundation for Research Science and Technology, New Zealand contracts C10X0308 and C10X0602.

\section{Acknowledgements}

The farm staff at the AgResearch Ruakura Animal Research Centre and Kim Wearne's help with immunization and tissue collections are greatly appreciated.

\section{References}

Bodensteiner KJ, Clay CM, Moeller CL \& Sawyer HR 1999 Molecular cloning of the ovine growth/differentiation factor-9 gene and expression of growth/differentiation factor-9 in ovine and bovine ovaries. Biology of Reproduction 60 381-386.

Braw-Tal R, McNatty KP, Smith P, Heath DA, Hudson NL, Phillips DJ, McLeod BJ \& Davis GH 1993 Ovaries of ewes homozygous for the X-linked Inverdale gene (FecXI) are devoid of secondary and tertiary follicles but contain many abnormal structures. Biology of Reproduction 49 895-907.

Carabatsos MJ, Elvin J, Matzuk MM \& Albertini DF 1998 Characterization of oocyte and follicle development in growth differentiation factor-9deficient mice. Developmental Biology 204 373-384.

Chang H, Brown CW \& Matzuk MM 2002 Genetic analysis of the mammalian transforming growth factor-beta superfamily. Endocrine Reviews 23 787-823.

Dixit H, Rao LK, Padmalatha V, Kanakavalli M, Deenadayal M, Gupta N, Chakravarty B \& Singh L 2005 Mutational screening of the coding region of growth differentiation factor 9 gene in Indian women with ovarian failure. Menopause 12 749-754.

Dixit H, Rao LK, Padmalatha VV, Kanakavalli M, Deenadayal M, Gupta N, Chakrabarty B \& Singh L 2006 Missense mutations in the BMP15 gene are associated with ovarian failure. Human Genetics 119 408-415.

Dong J, Albertini DF, Nishimori K, Kumar TR, Lu N \& Matzuk MM 1996 Growth differentiation factor-9 is required during early ovarian folliculogenesis. Nature $\mathbf{3 8 3} 531-535$.

Fatehi AN, van den Hurk R, Colenbrander B, Daemen AJ, van Tol HT, Monteiro RM, Roelen BA \& Bevers MM 2005 Expression of bone morphogenetic protein2 (BMP2), BMP4 and BMP receptors in the bovine ovary but absence of effects of BMP2 and BMP4 during IVM on bovine oocyte nuclear maturation and subsequent embryo development. Theriogenology 63 872-889. 
Galloway SM, McNatty KP, Cambridge LM, Laitinen MP, Juengel JL, Jokiranta TS, McLaren RJ, Luiro K, Dodds KG, Montgomery GW et al. 2000 Mutations in an oocyte-derived growth factor gene (BMP15) cause increased ovulation rate and infertility in a dosage-sensitive manner. Nature Genetics 25 279-283.

Hanrahan JP, Gregan SM, Mulsant P, Mullen M, Davis GH, Powell R \& Galloway SM 2004 Mutations in the genes for oocyte-derived growth factors GDF9 and BMP15 are associated with both increased ovulation rate and sterility in Cambridge and Belclare sheep (Ovis aries). Biology of Reproduction 70 900-909.

Juengel JL \& McNatty KP 2005 The role of proteins of the transforming growth factor-beta superfamily in the intraovarian regulation of follicular development. Human Reproduction Update 11 143-160.

Juengel JL, Hudson NL, Heath DA, Smith P, Reader KL, Lawrence SB, O'Connell AR, Laitinen MP, Cranfield M, Groome NP et al. 2002 Growth differentiation factor 9 and bone morphogenetic protein 15 are essential for ovarian follicular development in sheep. Biology of Reproduction 67 1777-1789.

Juengel JL, Bodensteiner KJ, Heath DA, Hudson NL, Moeller CL, Smith P, Galloway SM, Davis GH, Sawyer HR \& McNatty KP 2004a Physiology of GDF9 and BMP15 signalling molecules. Animal Reproduction Science 82-83 447-460.

Juengel JL, Hudson NL, Whiting L \& McNatty KP 2004b Effects of immunization against bone morphogenetic protein 15 and growth differentiation factor 9 on ovulation rate, fertilization, and pregnancy in ewes. Biology of Reproduction 70 557-561.

Kovanci E, Rohozinski J, Simpson JL, Heard MJ, Bishop CE \& Carson SA 2007 Growth differentiating factor-9 mutations may be associated with premature ovarian failure. Fertility and Sterility 87 143-146.

Laissue P, Christin-Maitre S, Touraine P, Kuttenn F, Ritvos O, Aittomaki K, Bourcigaux N, Jacquesson L, Bouchard P, Frydman R et al. 2006 Mutations and sequence variants in GDF9 and BMP15 in patients with premature ovarian failure. European Journal of Endocrinology 154 739-744.

McMahon HE, Hashimoto O, Mellon PL \& Shimasaki S 2008 Oocytespecific overexpression of mouse bone morphogenetic protein-15 leads to accelerated folliculogenesis and an early onset of acyclicity in transgenic mice. Endocrinology 149 2807-2815.

McNatty KP, Gibb M, Dobson C, Thurley DC \& Findlay JK 1981 Changes in the concentration of gonadotropic and steroidal hormones in the antral fluid of ovarian follicle throughout the oestrous cycle of the sheep. Australian Journal of Biological Science 34 67-80.

McNatty KP, Juengel JL, Wilson T, Galloway SM, Davis GH, Hudson NL, Moeller CL, Cranfield M, Reader KL, Laitinen MP et al. 2003 Oocytederived growth factors and ovulation rate in sheep. Reproduction Supplement 61 339-351.

McNatty KP, Juengel JL, Reader KL, Lun S, Myllymaa S, Lawrence SB, Western A, Meerasahib MF, Mottershead DG, Groome NP et al. 2005a Bone morphogenetic protein 15 and growth differentiation factor 9 co-operate to regulate granulosa cell function in ruminants. Reproduction 129 481-487.

McNatty KP, Smith P, Moore LG, Reader K, Lun S, Hanrahan JP, Groome NP, Laitinen M, Ritvos O \& Juengel JL 2005b Oocyte-expressed genes affecting ovulation rate. Molecular and Cellular Endocrinology 234 57-66.
McNatty KP, Hudson NL, Whiting L, Reader KL, Lun S, Western A, Heath DA, Smith P, Moore LG \& Juengel JL 2007 The effects of immunizing sheep with different BMP15 or GDF9 peptide sequences on ovarian follicular activity and ovulation rate. Biology of Reproduction $\mathbf{7 6}$ $552-560$

Moore RK, Erickson GF \& Shimasaki S 2004 Are BMP-15 and GDF-9 primary determinants of ovulation quota in mammals? Trends in Endocrinology and Metabolism 15 356-361.

Palmer JS, Zhao ZZ, Hoekstra C, Hayward NK, Webb PM, Whiteman DC, Martin NG, Boomsma DI, Duffy DL \& Montgomery GW 2006 Novel variants in growth differentiation factor 9 in mothers of dizygotic twins. Journal of Clinical Endocrinology and Metabolism 91 4713-4716.

Di Pasquale E, Beck-Peccoz P \& Persani L 2004 Hypergonadotropic ovarian failure associated with an inherited mutation of human bone morphogenetic protein-15 (BMP15) gene. American Journal of Human Genetics 75 106-111.

Di Pasquale E, Rossetti R, Marozzi A, Bodega B, Borgato S, Cavallo L, Einaudi S, Radetti G, Russo G, Sacco M et al. 2006 Identification of new variants of human BMP15 gene in a large cohort of women with premature ovarian failure. Journal of Clinical Endocrinology and Metabolism 91 1976-1979.

Shimizu T, Miyahayashi Y, Yokoo M, Hoshino Y, Sasada H \& Sato E 2004 Molecular cloning of porcine growth differentiation factor 9 (GDF-9) cDNA and its role in early folliculogenesis: direct ovarian injection of GDF-9 gene fragments promotes early folliculogenesis. Reproduction 128 537-543.

Spicer LJ, Aad PY, Allen D, Mazerbourg S \& Hsueh AJ 2006 Growth differentiation factor-9 has divergent effects on proliferation and steroidogenesis of bovine granulosa cells. Journal of Endocrinology 189 329-339.

Spicer LJ, Aad PY, Allen DT, Mazerbourg S, Payne AH \& Hsueh AJ 2008 Growth differentiation factor 9 (GDF9) stimulates proliferation and inhibits steroidogenesis by bovine theca cells: influence of follicle size on responses to GDF9. Biology of Reproduction 78 243-253.

Vitt UA, McGee EA, Hayashi M \& Hsueh AJ 2000 In vivo treatment with GDF-9 stimulates primordial and primary follicle progression and theca cell marker CYP17 in ovaries of immature rats. Endocrinology 141 3814-3820.

Wu X, Chen L, Brown CA, Yan C \& Matzuk MM 2004 Interrelationship of growth differentiation factor 9 and inhibin in early folliculogenesis and ovarian tumorigenesis in mice. Molecular Endocrinology 18 1509-1519.

Yan C, Wang P, DeMayo J, DeMayo FJ, Elvin JA, Carino C, Prasad SV, Skinner SS, Dunbar BS, Dube JL et al. 2001 Synergistic roles of bone morphogenetic protein 15 and growth differentiation factor 9 in ovarian function. Molecular Endocrinology 15 854-866.

Received 13 January 2009

First decision 10 March 2009

Accepted 13 May 2009 